\title{
PERCEPTION OF BUSINESS ENVIRONMENT BY SMALL AND MEDIUM ENTERPRISES
}

\author{
[Vnímání podnikatelského prostředí prizmatem malých a středních podniků]

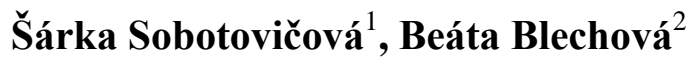 \\ ${ }^{1}$ Slezská univerzita, Obchodně podnikatelská fakulta, Univerzitní nám. 1934/3, 73340 Karviná \\ Email:sobotovicova@opf.slu.cz. \\ ${ }^{2}$ Slezská univerzita, Obchodně podnikatelská fakulta, Univerzitní nám. 1934/3, 73340 Karviná \\ Email:blechova@opf.slu.cz
}

\begin{abstract}
Paper focuses on small and medium-sized enterprises in context of their perception of the business environment. Small and medium-sized enterprises need for their development and operation a favourable business environment and a level of support in business activities, both from the state and from their environment. The aim of the research is to identify and verify how small and medium-sized enterprises in the Czech Republic perceive the public's attitude toward their business activities, the level of administrative burden and business conditions created by the state. Based on the survey, it was found that despite the measures taken by state to improve conditions for business, respondents don't feel the improvement of business conditions or reduction of administrative burden.
\end{abstract}

Keywords: administrative burden, business environment, small and medium-sized enterprises, state support.

JEL classification: $\mathrm{H} 3, \mathrm{~K} 2, \mathrm{M} 1$

Doručeno redakci: 28.4.2016; Recenzováno: 3.5.2016; 9.5.2016; Schváleno k publikování: 24.8.2016

\section{Úvod}

Článek je zaměřen na výzkum malých a středních podniků v České republice v souvislosti s jejich vnímáním podnikatelského prostředí. Malé a střední podniky tvoří důležitou součást ekonomiky nejen Evropské unie, ale rovněž jednotlivých členských států. Ani Česká republika, kde představuje sektor malých a středních podniků největší skupinu podnikatelských subjektů, není výjimkou. Malé a střední podniky jsou nepostradatelným zdrojem růstu, zaměstnanosti, podnikatelských dovedností a inovací. Představitelé Evropské unie si tento potenciál velice dobře uvědomují a $\mathrm{v}$ posledních letech zaměřují na sektor malých a středních podniků velkou pozornost. Jejich cílem je co nejvíce zkvalitnit podnikatelské prostředí a tím zlepšit podmínky pro fungování již existujících podniků, ale také motivovat k založení nových podniků.

V roce 1996 Evropská komise stanovila první všeobecnou definici malého a středního podnikání. Jelikož od té doby došlo $\mathrm{k}$ významnému ekonomickému rozvoji, přistoupila Evropská komise v roce 2003 k přijetí nové definice, která vešla v platnost k 1. lednu 2005 a její použití členskými státy je povinné (Evropská komise, 2015). 
Tabulka 1: Hranice pro zařazení do jednotlivých skupin MSP

\begin{tabular}{|l|l|l|l|l|l|}
\hline \multirow{2}{*}{ Kategorie } & \multirow{2}{*}{$\begin{array}{l}\text { Počet } \\
\text { zaměstnanců }\end{array}$} & Roční obrat & \multicolumn{2}{l|}{ Roční rozvaha } \\
\cline { 3 - 6 } & $<996$ & 2005 & 1996 & 2005 \\
\hline Střední podnik & $<250$ & $\leq € 40$ mil. & $\leq € 50$ mil. & $\leq € 27$ mil. & $\leq € 43$ mil. \\
\hline Malý podnik & $<50$ & $\leq € 7$ mil. & $\leq € 10$ mil. & $\leq € 5$ mil. & $\leq € 10$ mil. \\
\hline Mikropodnik & $<10$ & $\begin{array}{l}\text { nebylo } \\
\text { definováno }\end{array}$ & $\leq € 2$ mil. & $\begin{array}{l}\text { nebylo } \\
\text { definováno }\end{array}$ & $\leq € 2$ mil. \\
\hline
\end{tabular}

Zdroj: Evropská komise, 2015. User guide to the SME definitiv. Luxembourg: Publications Office of the European Union. ISBN 978-92-79-45322-9.

Malé a střední podniky v roce 2014 představovaly 99,8 \% všech podniků v nefinančním podnikatelském sektoru v EU28. V roce 2014 malé a střední podniky zaměstnávaly téměř 90 milionů lidí což je $67 \%$ z celkové zaměstnanosti v EU28. Malé a stř̌ední podniky představují pro ekonomiku Evropské unie významný prvek a z toho důvodu je potřeba brát v úvahu jejich zájmy nejen na úrovni Evropské unie, ale také v jednotlivých členských státech, jelikož tyto podniky mají schopnost rychle reagovat na změny podmínek a představují obrovskou ekonomickou sílu.

\section{Malé a střední podnikání v České republice}

Dle Koncepce podpory malých a středních podnikatelů na období let 2014-2020 je jednou z priorit vlády ČR podpora konkurenceschopnosti malých a středních podnikatelů, kteří reprezentují více než 1 milion ekonomických subjektů v České republice, tj. 99,84 \% všech podnikatelů. Malé a střední podniky se na vývozu podílí cca $51 \%$ a na dovozu cca $56 \%$. Současně zaměstnávají přes 1,8 mil. zaměstnanců a podíl zaměstnanců malých a středních podniků na celkovém počtu zaměstnanců podnikatelské sféry v Č́R v roce 2014 činil 59,39 \%. Malé a střední podniky mají rovněž podstatný význam pro rozvoj jednotlivých krajů v České republice, protože jsou významně podnikatelsky i společensky spjaty s daným regionem.

Obrázek 1: Vývoj aktivních subjektů v ČR v letech 2009-2014

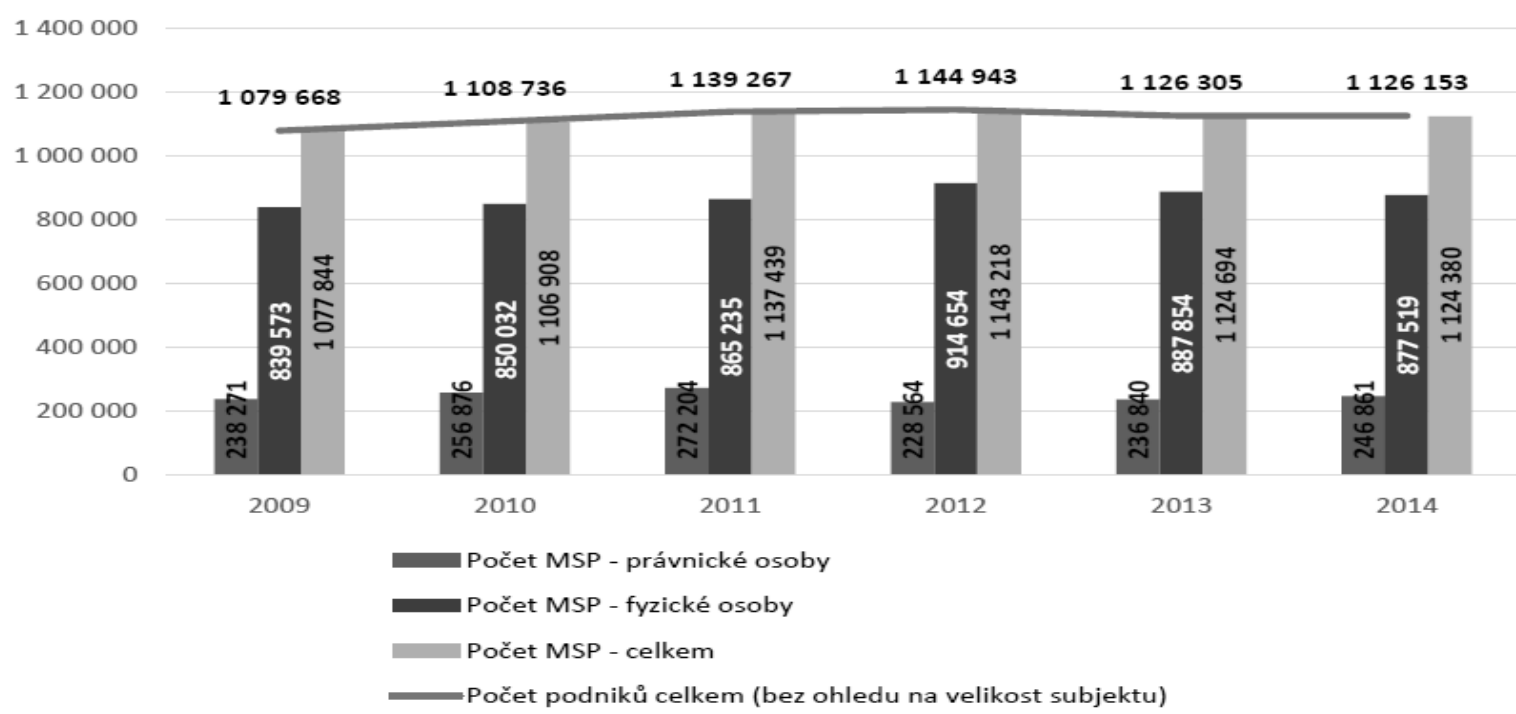

Zdroj: Zpráva o vývoji malého a středního podnikání a jeho podpoře v roce 2014 vypracována Ministerstvem průmyslu a obchodu na základě zákona č. 47/2002 Sb., o podpoře malého a středního podnikání [online] [vid. 24. záŕí 2015]. Dostupné z: www.mpo.cz/dokument164106.html

Hlavním cílem, který je stanoven v Koncepci podpory MSP 2014-2020 je „kontinuální posilování konkurenceschopnosti a ekonomické výkonnosti malých a středních podnikatelü založené na kvalitním podnikatelském prostředí, na využití a rozvoji jejich inovačního 
potenciálu, znalostech a vzdělávání, internacionalizaci vyplývající z vnitřního trhu EU a perspektivnich trhů ve třetích zemích a celkovém snižování energetické náročnosti podnikání".

Pro úspěšný rozvoj malého a středního podnikání je důležité vytvořit vhodný strategický a institucionální rámec, který podpoří úspěšný rozvoj vhodných podnikatelských podmínek. Strategický rámec pro rozvoj malého a středního podnikání představuje soubor dokumentů, mezi které je $\mathrm{v}$ České republice řazena především Strategie hospodářského růstu ČR a Koncepce rozvoje malého a středního podnikání.

Malé a střední podnikání potřebuje pro svůj rozvoj a fungování př́iznivé podnikatelské prostředí a určitou míru podpory $\mathrm{v}$ podnikatelských aktivitách jak na státní, tak evropské úrovni. Bohužel malé a střední podniky se stále potýkají s množstvím překážek v podobě administrativních a legislativních procedur, často čelí špatné dostupnosti kapitálu, ale i nedostatku kvalifikovaných sil. Je důležité, aby podnikatelská aktivita nebyla nadbytečně omezována administrativními bariérami a neefektivností ve fungování státní správy. Jelikož v důsledku průběžného zavádění různých legislativních opatření, je daňový systém podnikateli vnímán jako přiliš složitý, vyžaduje od poplatníků vyplňování značného množství údajů a představuje pro ně vysoké náklady na výpočet správné výše daňových odvodů (Blechová 2012).

Sektor malého a středního podnikání má nezastupitelnou úlohu $\mathrm{v}$ rámci tržní ekonomiky a tudíž je nezbytné, aby malí a střední podnikatelé měli pro svoji činnost vhodné podnikatelské prostředí, které by jim umožnilo posílit sociální soudržnost a přispívat k ekonomickému růstu.

\section{Teoretické a empirické přístupy zaměřené na podmínky malých a středních podniků}

Zkoumání kvality podnikatelského prostředí je věnována pozornost na celosvětové úrovni. Např́klad Ahmad (2012) zkoumá hlavní omezení růstu malých a středních podniků v Království Saudské Arábie. Dle Dujowich (2010) jsou míra nezaměstnanosti, hospodářský růst, a růst podnikání vzájemně propojeny. Podobně Thurik et al. (2008), Ghavidel a Farjadi (2011) zkoumají vztah mezi podnikáním a mírou nezaměstnanosti.

Mnoho výzkumných studií se zabývá administrativními náklady jak v zemích OECD, tak i mimo ně. Např́íklad Lignier a Evans (2012) se ve své studii zabývali administrativními náklady vyvolanými daňovým systémem, které nesou malé a střední firmy v Austrálii. Jejich studie je součástí mezinárodního výzkumného projektu, který zjišt'uje a porovnává administrativní náklady malých a středních podniků ve vybraných zemích. Výsledky ukazují, že obtíže $\mathrm{v}$ př́istupu $\mathrm{k}$ finančním zdrojům, byrokratické překážky a nepříznivé podnikatelské prostředí, jsou hlavními překážkami pro fungování malých a středních podniků ve většině států.

Jedním z charakteristických rysů malých podniků jsou jejich omezené finanční zdroje, které nabízejí méně možností pro zaměstnávání odborníků $\mathrm{s}$ dovednostmi specializovanými na řízení, účetnictví a daně. Empirické průzkumy prokazují, že náklady spojené s dodržováním předpisů, jsou pro malé a stř̌ední podniky vyšší než pro velké. Přitom vysoké náklady na dodržení daňových předpisů mohou zpomalit ekonomiku, jelikož malé a střední podniky jsou považovány za důležité faktory ekonomického růstu (Weichenrieder 2007). 
Problematice administrativní zátěže podnikatelů věnuje velkou pozornost Evropská komise již od roku 2002. Členským státům doporučila provést obdobná opatření na národní úrovni. V současné době je problematika úzce propojena s dalšími dokumenty Evropské unie (Evropa 2020 - Udržitelný růst, Konkurenceschopnost - prioritou je zlepšení podnikatelského prostředí $\mathrm{v}$ rámci prioritní iniciativy Evropské unie "Průmyslová politika pro éru globalizace"). Mezi kroky, které komise navrhuje k odstranění překážek na jednotném trhu je také prosazení programu promyšlených právních předpisů, zhodnocení stávajících právních předpisů ex-post, snížení administrativní zátěže, zlepšení podnikatelského prostředí, zejména pro malé a střední podniky a podpora podnikání. V rámci Evropské unie je v současné době aktuální trend snižování administrativního zatížení pro malé a střední podniky (Blackburn et. al 2005, Sopková a Sujová 2011).

V České republice se problematice malých a středních firem z hlediska jejich úspěšnosti, vnímání podnikatelského prostředí a vlivu na ekonomický růst věnují např. Kubičcková a Procházková (2014). Jak uvádí Lacina a Vavřina (2013) malé a střední podniky se s větší pravděpodobností potýkají s vyššími náklady na bankovní úvěry nebo půjčky a s vyšší mírou zamítnutí než větší firmy. Kvalitou podnikatelského prostředí malých a středních podniků se zabývají ve svých výzkumech Belás, Bartoš, Ključnikov a Kozubíková (2015). Podle průzkumu Vaštíkové a Matušínské (2014) existuje mnoho možností zlepšení, které mohou ovlivnit a podpořit kvalitní podnikatelské prostředí ze strany obcí pro malé a střední firmy, které se na činnosti obcí podílejí aktivním způsobem. Přístupem k vnímání a řízení podnikových rizik u malých a středních podniků v České republice a na Slovensku se ve své studii zabývali Kozubíková, Belás, Bilan a Bartoš (2015). Analýzou nákladů vyplývajících podnikajícím plátcům daní z důvodu existence daňového systému se ve své studii zabývali Vítek a Pavel (2008).

Snižování administrativní zátěže, podpora podnikání, zjednodušování legislativy je v České republice také součástí programových prohlášení vlád. Např́klad v roce 2010 bylo v programovém prohlášení urychlené dokončení projektu Jednotného inkasního místa (JIM), přijetí nového zákona o daních z př́ijmů, který měl zrušit většinu daňových výjimek a tím zjednodušit a zpřehlednit daňový systém a snížit administrativní náklady na straně státu i podnikatelů.

V programovém prohlášení vlády (2014) je uvedeno: „Vláda podpoři rozvoj malého a středního podnikání, které stále představuje nevyužitou rezervu růstu a zaměstnanosti. Vláda podnikne kroky k maximálnímu snižování administrativní zátěže pro podnikatele. “

Jak uvádí Ministerstvo průmyslu a obchodu (2015) bylo v Plánu v letech 2008 až 2012 schváleno 53 opatření pro snížení administrativní zátěže podnikatelů a v letech 2013 a 2014 přibylo dalších 26. Celkový počet sledovaných opatření se tím rozšířil na 79. Některá z nich již byla splněna, jedná se např́íklad o:

- odstranění výkladových nejasností u daně z nemovitých věcí,

- začlenění daně dědické a daně darovací do zákona o daních z př́ijmů,

- reorganizaci orgánů finanční správy, za účelem zjednodušení plnění daňových povinností u daně z nemovitých věcí.

Na druhou stranu některé legislativní změny přinášejí podnikatelům i zvýšení administrativní zátěže. Jedná se např́klad o zavedení rozdílných částek daňového zvýhodnění či nové slevy za umístění dítěte. Stejně tak dochází ke zvýšení administrativní zátěže v souvislosti s opatřeními pro snížení daňových úniků u daně z přidané hodnoty, např́íklad zavedením kontrolního hlášení. 


\section{Empirický výzkum a použité metody}

V návaznosti na opatření Evropské unie a také České republiky, která jsou zaměřena na snižování administrativní zátěže a zlepšení podmínek pro podnikání, bylo realizováno výzkumné šetření. Cílem výzkumu bylo zjistit, jak podnikatelé vnímají podmínky pro podnikání malých a středních podniků v České republice. Jednalo se o kvalitativní výzkum, na základě kterého byly pomocí škálových otázek získány ordinální proměnné.

\subsection{Použité metody}

Data získaná v dotazníkovém šetření v rámci výzkumu realizovaného v roce 2015 byla utř́iěna do frekvenční tabulky, která obsahuje následující informace:

- pořadové číslo obměny (i),

- hodnota znaku (xi),

- absolutní četnost (ni),

- relativní četnost (pi),

- kumulativní relativní četnost (kpi).

Hodnota znaku vyjadřuje přehled všech obměn, které proměnná nabývá. Další neméně důležitou informací, kterou je nutno z frekvenční tabulky vyčíst, je tzv. absolutní četnost, která uvádí, kolikrát se daná hodnota v databázi vyskytuje. Součet všech absolutních četností se rovná rozsahu souboru $n$.

Vzhledem k tomu, že absolutní četnosti vždy závisí na rozsahu souboru, je vhodné je vyjádřit $\mathrm{v}$ procentech. Jedná se o relativní četnost, která je vypočtena podle vzorce (1):

$$
p_{i}=\frac{n_{i}}{n}
$$

Součet všech relativních četností je vždy 100 \%. Pro ordinální znaky byla vypočtena také kumulativní relativní četnosti podle vzorce (2):

$$
k p_{j}=\sum_{j=1}^{i} p_{j}
$$

Poloha je u ordinální proměnné charakterizována modální kategorií, což je kategorie s největší četností. Jestliže jsou kategorie označeny indexem i $(i=1,2, \ldots, \mathrm{K}$, kde $\mathrm{K}$ je počet kategorií), $n_{\mathrm{i}}$ jsou absolutní četnosti a $\mathrm{p}_{\mathrm{i}}$ relativní četnosti, pak $\max \mathrm{n}_{\mathrm{i}}=\mathrm{nMo}$ a $\max \mathrm{p}_{\mathrm{i}}=\mathrm{pMo}$. Tyto četnosti modální kategorie se rovněž nazývají modální. Jestliže pMo $>0,5$, pak můžeme modální kategorii označit též jako majoritní a četnosti nMo a pMo rovněž jako majoritní (̌̌ezanková 2011).

\subsection{Dotazníkové šetřrení}

V dotazníku byly využity zejména škálové otázky, které jsou nejvhodnějším nástrojem pro měření názorů a postojů. Použitím Likertovy škály byl zjišs’ován nejen obsah postoje, ale i jeho přibližná síla. Požadavky na vytvoření Likertovy škály jsou obecně chápány poměrně jednoznačně - škála by měla být polarizována od nesouhlasu po souhlas (tedy nikoliv jednostranně), a sice s lichým počtem stupňů. Ke zkoumané problematice byla vytvořena tvrzení v podobě kladného stanoviska (Stát pomáhá při podnikání: Úplně souhlasím Souhlasím - Indiference - Nesouhlasím - Úplně nesouhlasím). Výzkum probíhal v roce 2015, osloveno bylo 1650 firem vybraných náhodným způsobem z databáze Albertina prostřednictvím dotazníku umístěného na webových stránkách a zčásti telefonicky 
a e-mailem. Návratnost byla $69 \%$ a do zpracování bylo zahrnuto 1141 dotazníků. Struktura respondentů podle velikosti podniku je uvedena v následující tabulce.

Tabulka 2: Struktura respondentů podle velikosti podniku

\begin{tabular}{|l|l|l|}
\hline velikost & počet & v \% \\
\hline mikropodnik & 740 & 65 \\
\hline malý podnik & 306 & 27 \\
\hline střední podnik & 95 & 8 \\
\hline
\end{tabular}

V následujícím obrázku je znázorněna struktura respondentů podle oboru podnikání. Z obrázku je zřejmé, že převažovaly podniky v oblasti služeb, obchodu a výroby, což jsou charakteristické oblasti pro podnikání malých a středních podniků (MSP).

Obrázek 2: Struktura respondentů podle oboru podnikání

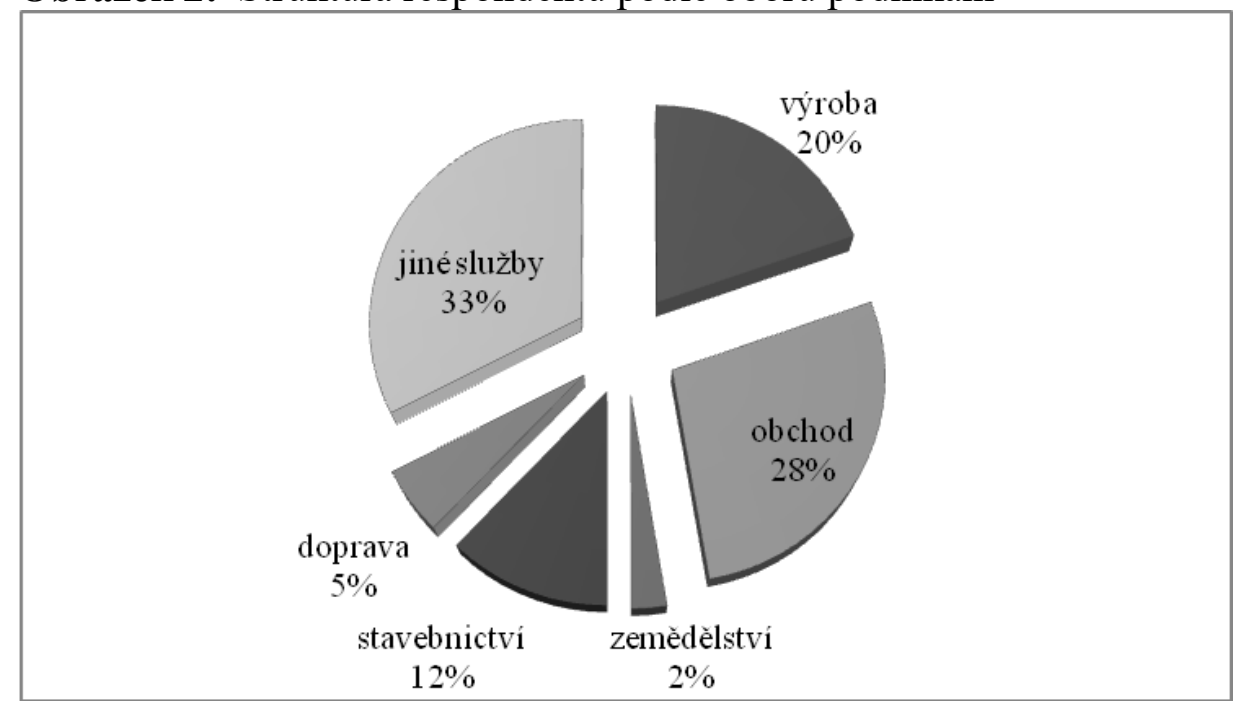

Zdroj: vlastní zpracování

Byly formulovány tři základní výzkumné otázky:

- Vytváríi stát př́íznivé podmínky pro podnikání malých a středních podniků?

- Jaký je postoj veřejnosti k podnikatelům?

- Zlepšují se podmínky pro podnikání a snižuje se administrativní zátěž?

Na základě stanovených oblastí výzkumu byly otázky pro účely vyhodnocení rozděleny do tří kategorií.

\subsection{Vnímání podnikatelského prostř̌edí}

V rámci zkoumání podmínek pro podnikání bylo zjišt’ováno, jak malé a střední podniky vnímají podporu státu pro své podnikatelské činnosti a jak hodnotí př́stup státu k tvorbě př́znivého podnikatelského prostředí. Byla formulována čtyři tvrzení, ke kterým podnikatelé vyjadřovali míru souhlasu:

1. Stát pomáhá podnikatelům při podnikání.

2. Podnikatelské prostředí v České republice hodnotím jako vhodné pro zahájení podnikání.

3. Stát vytváří prríznivé podnikatelské prostředí pro MSP.

4. Mám pocit, že stát nás při podnikání šikanuje. 


\section{Vyhodnocení míry souhlasu}

V následujících tabulkách je vyjádřena míra souhlasu s jednotlivými tvrzeními na základě odpovědí respondentů.

Tabulka 3: Stát pomáhá podnikatelům při podnikání.

\begin{tabular}{|l|l|l|l|}
\hline míra souhlasu $\mathrm{x}_{\mathrm{i}}$ & $\mathrm{n}_{\mathrm{i}}$ & $\mathrm{p}_{\mathrm{i}}(\%)$ & $\mathrm{kp}_{\mathrm{i}}(\%)$ \\
\hline úplně souhlasím & 10 & 0,88 & 0,88 \\
\hline souhlasím & 117 & 10,25 & 11,13 \\
\hline nezaujímám postoj & 301 & 26,38 & 37,51 \\
\hline nesouhlasím & 532 & 46,63 & 84,14 \\
\hline úplně nesouhlasím & 181 & 15,86 & 100,00 \\
\hline celkem & 1141 & 100 & $\mathrm{x}$ \\
\hline
\end{tabular}

Zdroj: vlastní zpracování

Na základě údajů ve výše uvedené tabulce je možno konstatovat, že modální kategorií je nesouhlas s tímto tvrzením (46,63\% respondentů). Celkově je možno říci, že pouze $11,13 \%$ podnikatelů souhlasí s konstatováním, že stát pomáhá podnikatelům při podnikání.

Tabulka 4: Podnikatelské prostředí v ČR hodnotím jako vhodné pro zahájení podnikání.

\begin{tabular}{|l|l|l|l|}
\hline míra souhlasu $\mathrm{x}_{\mathrm{i}}$ & $\mathrm{n}_{\mathrm{i}}$ & $\mathrm{p}_{\mathrm{i}}(\%)$ & $\mathrm{kp}_{\mathrm{i}}(\%)$ \\
\hline úplně souhlasím & 15 & 1,31 & 1,31 \\
\hline souhlasím & 323 & 28,31 & 29,62 \\
\hline nezaujímám postoj & 285 & 24,98 & 54,60 \\
\hline nesouhlasím & 446 & 39,09 & 93,69 \\
\hline úplně nesouhlasím & 72 & 6,31 & 100,00 \\
\hline celkem & 1141 & 100 & $\mathrm{x}$ \\
\hline
\end{tabular}

Zdroj: vlastní zpracování

Obdobný trend je možno sledovat také v tabulce 4 , kde je opět modální kategorií nesouhlas s tvrzením, že podnikatelské prostředí v ČR je vhodné pro zahájení podnikání $(39,09 \%$ respondentů). Na druhou stranu počet respondentů, kteří s tvrzením souhlasí, je vyšší $(29,62 \%)$. Tato skutečnost může být ovlivněna částečným zjednodušením podmínek pro zahájení podnikání, jednak prostřednictvím centrálního registračního místa na živnostenském úřadě nebo také snížením vkladu při založení společnosti s ručením omezeným.

Tabulka 5: Stát vytváří příznivé podnikatelské prostředí pro MSP.

\begin{tabular}{|l|l|l|l|}
\hline míra souhlasu $\mathrm{x}_{\mathrm{i}}$ & $\mathrm{n}_{\mathrm{i}}$ & $\mathrm{p}_{\mathrm{i}}(\%)$ & $\mathrm{kp}_{\mathrm{i}}(\%)$ \\
\hline úplně souhlasím & 3 & 0,26 & 0,26 \\
\hline souhlasím & 96 & 8,41 & 8,68 \\
\hline nezaujímám postoj & 346 & 30,32 & 39,00 \\
\hline nesouhlasím & 585 & 51,27 & 90,27 \\
\hline úplně nesouhlasím & 111 & 9,73 & 100,00 \\
\hline celkem & 1141 & 100 & $\mathrm{x}$ \\
\hline
\end{tabular}

Zdroj: vlastní zpracování

Také na základě hodnot v tabulce 5 bylo zjištěno, že modální kategorií je nesouhlas s tvrzením, že stát vytváří prř́znivé podnikatelské prostředí pro malé a stř̌ední podniky. Jelikož pMo $>0,5$, můžeme tuto modální kategorii označit také jako majoritní. Souhlas s výrokem vyjádřil nejmenší počet respondentů, a to pouze $8,68 \%$. 
Tabulka 6: Mám pocit, že stát nás při podnikání šikanuje.

\begin{tabular}{|l|l|l|l|}
\hline míra souhlasu $\mathrm{x}_{\mathrm{i}}$ & $\mathrm{n}_{\mathrm{i}}$ & $\mathrm{p}_{\mathrm{i}}(\%)$ & $\mathrm{kp}_{\mathrm{i}}(\%)$ \\
\hline úplně souhlasím & 153 & 13,41 & 13,41 \\
\hline souhlasím & 438 & 38,39 & 51,80 \\
\hline nezaujímám postoj & 350 & 30,67 & 82,47 \\
\hline nesouhlasím & 178 & 15,60 & 98,07 \\
\hline úplně nesouhlasím & 22 & 1,93 & 100,00 \\
\hline celkem & 1141 & 100 & $\mathrm{x}$ \\
\hline
\end{tabular}

Zdroj: vlastní zpracování

Toto tvrzení prezentuje negativní přístup státu k podnikání. To se také odrazilo v odpovědích respondentů a modální kategorií je souhlas s tvrzením, který vyjádřilo 38,39 \% respondentů a také celkově převládá souhlasné stanovisko s výrokem (tabulka 6).

Výsledky této skupiny tvrzení jsou znázorněny v následujícím obrázku. Na základě srovnání je vidět, že u tvrzení jedna až tři převažuje stanovisko nesouhlasné. Souhlas je převládající pouze u tvrzení číslo 4, které prezentuje názor, že stát podnikatele při podnikání šikanuje.

Obrázek 3: Vnímání podnikatelského prostředí

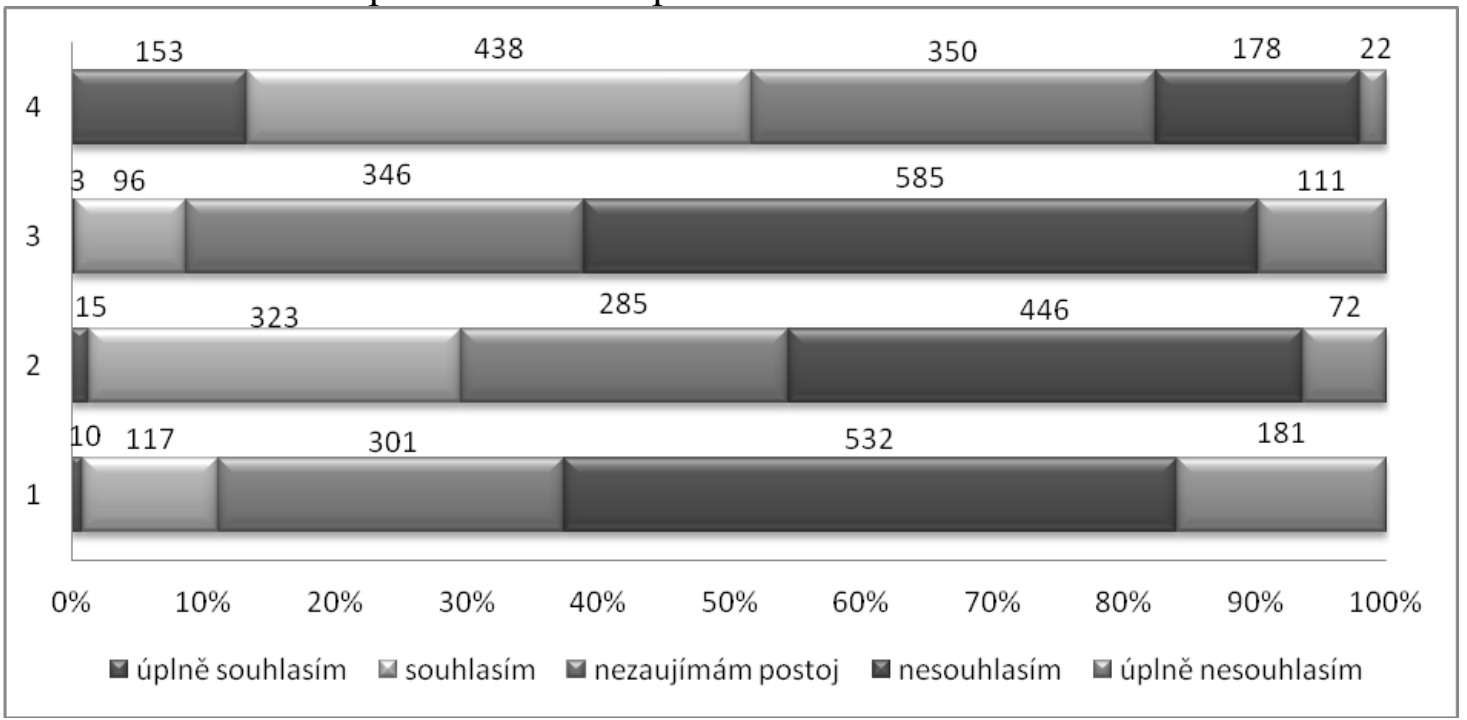

Zdroj: vlastní zpracování

$\mathrm{Na}$ základě výše uvedeného je možno zhodnotit, že podnikatelé vnímají nedostatečnou podporu ze strany státu pro své podnikání a také podnikatelské prostředí v České republice není hodnoceno jako př́znivé.

\subsection{Vnímání postoje okolí}

V rámci zkoumání postoje okolí bylo zjišt'ováno, jak malé a střední podniky vnímají podporu svých podnikatelských aktivit ze strany veřejnosti, politiků a médií. Byla formulována čtyři tvrzení, ke kterým podnikatelé vyjadřovali míru souhlasu:

5. Cítím podporu svého okolí $\mathrm{k}$ mým podnikatelským aktivitám.

6. Při komunikaci s lidmi cítím, že oceňují skutečnost, že podnikám.

7. Politici a veřejné mínění si uvědomují přínos podnikatelů pro společnost.

8. Média nedostatečně informují o významu podnikatelů pro společnost.

\section{Vyhodnocení míry souhlasu}

V následujících tabulkách je vyjádřena míra souhlasu s jednotlivými tvrzeními na základě odpovědí respondentů. 
Tabulka 7: Cítím podporu svého okolí k mým podnikatelským aktivitám.

\begin{tabular}{|l|l|l|l|}
\hline míra souhlasu $\mathrm{x}_{\mathrm{i}}$ & $\mathrm{n}_{\mathrm{i}}$ & $\mathrm{p}_{\mathrm{i}}(\%)$ & $\mathrm{kp}_{\mathrm{i}}(\%)$ \\
\hline úplně souhlasím & 189 & 16,56 & 16,56 \\
\hline souhlasím & 542 & 47,50 & 64,07 \\
\hline nezaujímám postoj & 279 & 24,45 & 88,52 \\
\hline nesouhlasím & 108 & 9,47 & 97,98 \\
\hline úplně nesouhlasím & 23 & 2,02 & 100,00 \\
\hline celkem & 1141 & 100 & $\mathrm{x}$ \\
\hline
\end{tabular}

Zdroj: vlastní zpracování

Z tabulky 7 vyplývá, že většina respondentů vnímá pozitivně podporu svého okolí (kumulativní relativní četnost je přes 64 \%) a modální kategorií je souhlas s tvrzením.

Tabulka 8: Při komunikaci s lidmi cítím, že oceňují skutečnost, že podnikám.

\begin{tabular}{|l|l|l|l|}
\hline míra souhlasu $\mathrm{x}_{\mathrm{i}}$ & $\mathrm{n}_{\mathrm{i}}$ & $\mathrm{p}_{\mathrm{i}}(\%)$ & $\mathrm{kp}_{\mathrm{i}}(\%)$ \\
\hline úplně souhlasím & 95 & 8,33 & 8,33 \\
\hline souhlasím & 584 & 51,18 & 59,51 \\
\hline nezaujímám postoj & 309 & 27,08 & 86,59 \\
\hline nesouhlasím & 129 & 11,31 & 97,90 \\
\hline úplně nesouhlasím & 24 & 2,10 & 100,00 \\
\hline celkem & 1141 & 100 & $\mathrm{x}$ \\
\hline
\end{tabular}

Zdroj: vlastní zpracování

Také na základě hodnot v tabulce 8 bylo stanoveno, že modální kategorií je souhlas tvrzením, hodnota pMo > 0,5 a proto se jedná o kategorii majoritní. Stejně jako u předchozího tvrzení nesouhlas vyjádřila pouze minoritní skupina respondentů (v tomto př́ipadě pouze $13,41 \%$ ).

Tabulka 9: Politici a veřejné mínění si uvědomují př́ínos podnikatelů pro společnost.

\begin{tabular}{|l|l|l|l|}
\hline míra souhlasu $\mathrm{x}_{\mathrm{i}}$ & $\mathrm{n}_{\mathrm{i}}$ & $\mathrm{p}_{\mathrm{i}}(\%)$ & $\mathrm{kp}_{\mathrm{i}}(\%)$ \\
\hline úplně souhlasím & 11 & 0,96 & 0,96 \\
\hline souhlasím & 186 & 16,30 & 17,27 \\
\hline nezaujímám postoj & 231 & 20,25 & 37,51 \\
\hline nesouhlasím & 559 & 48,99 & 86,50 \\
\hline úplně nesouhlasím & 154 & 13,50 & 100,00 \\
\hline celkem & 1141 & 100 & $\mathrm{x}$ \\
\hline
\end{tabular}

Zdroj: vlastní zpracování

Odlišná je situace u tvrzení, že si politici a veřejné mínění uvědomují přínos podnikatelů pro společnost. Zde je obdobně jako u tvrzení ohledně podpory státu modální kategorií nesouhlas s tvrzením. A s tímto výrokem vyjádřilo souhlas jen 17,27 \% dotázaných, jak vyplývá z tabulky 9 .

Tabulka 10: Média nedostatečně informují o významu podnikatelů pro společnost.

\begin{tabular}{|l|l|l|l|}
\hline míra souhlasu $\mathrm{x}_{\mathrm{i}}$ & $\mathrm{n}_{\mathrm{i}}$ & $\mathrm{p}_{\mathrm{i}}(\%)$ & $\mathrm{kp}_{\mathrm{i}}(\%)$ \\
\hline úplně souhlasím & 171 & 14,99 & 14,99 \\
\hline souhlasím & 640 & 56,09 & 71,08 \\
\hline nezaujímám postoj & 228 & 19,98 & 91,06 \\
\hline nesouhlasím & 87 & 7,62 & 98,69 \\
\hline úplně nesouhlasím & 15 & 1,31 & 100,00 \\
\hline celkem & 1141 & 100 & $\mathrm{x}$ \\
\hline
\end{tabular}

Zdroj: vlastní zpracování

Výše uvedený výrok prezentuje negativní přístup médií k poskytování informací o významu podnikatelů pro společnost. Jak vyplývá z tabulky 10 , s tímto tvrzení souhlasí až $71,08 \%$ dotazovaných a majoritní modální kategorií je souhlas. 
Na základě níže uvedeného obrázku je možno rekapitulovat postoj respondentů. Bylo zjištěno, že vztah okolí a veřejnosti k podnikatelům je vnímán kladně. Jiná je situace při zjišt'ování postoje $\mathrm{k}$ názoru politiků a veřejného mínění $\mathrm{k}$ přínosu podnikatelů pro společnost. S tímto výrokem nesouhlasilo $62,49 \%$ dotazovaných. Tato skutečnost může být ovlivněna také nedostatečným poskytováním informací o významu podnikatelů v médiích, kterou pocit'uje většina respondentů.

Obrázek 4: Vnímání postoje okolí

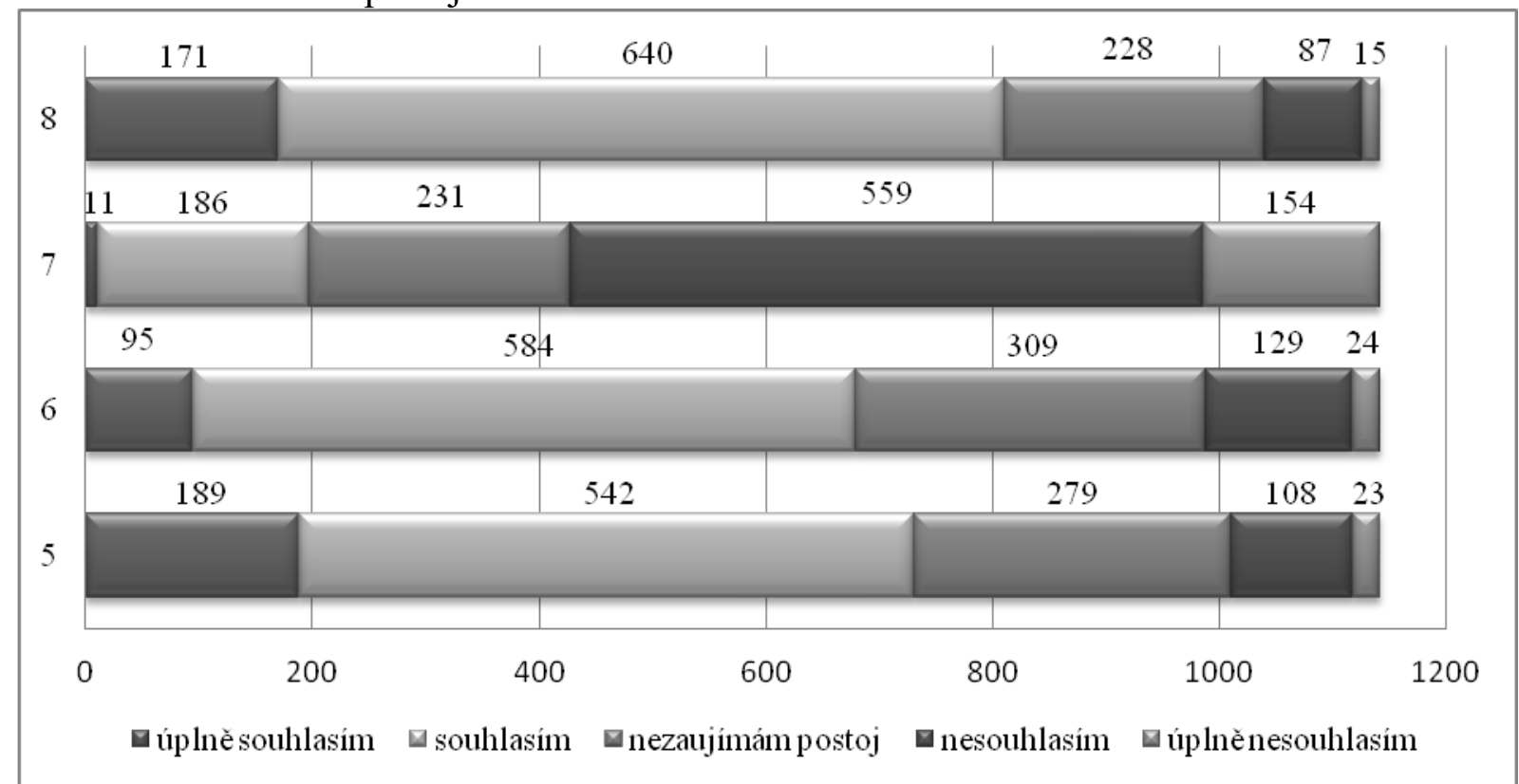

Zdroj: vlastní zpracování

\subsection{Vývoj podmínek a administrativní zátěže}

Vzhledem k tomu, že zjednodušení podmínek pro podnikání a snížení administrativní zátěže zejména malých a středních podnikatelů vyplývá jak z programového prohlášení vlády, tak i z př́stupu Evropské unie, byl zjišt'ován také postoj respondentů v těchto oblastech. Byla formulována dvě tvrzení, ke kterým podnikatelé vyjadřovali míru souhlasu:

9. Podmínky pro podnikání se za posledních 5 let zlepšily.

10. Administrativní zátěž podnikatelů se za posledních pět let snížila.

\section{Vyhodnocení míry souhlasu}

V následujících tabulkách je vyjádřena míra souhlasu s jednotlivými tvrzeními na základě odpovědí respondentů.

Tabulka 11: Podmínky pro podnikání se za posledních 5 let zlepšily.

\begin{tabular}{|l|r|r|r|}
\hline${\text { míra souhlasu } \mathrm{x}_{\mathrm{i}}}^{\mathrm{n}_{\mathrm{i}}}$ & $\mathrm{p}_{\mathrm{i}}(\%)$ & $\mathrm{kp}_{\mathrm{i}}(\%)$ \\
\hline úplně souhlasím & 7 & 0,61 & 0,61 \\
\hline souhlasím & 229 & 20,07 & 20,68 \\
\hline nezaujímám postoj & 281 & 24,63 & 45,31 \\
\hline nesouhlasím & 516 & 45,22 & 90,53 \\
\hline úplně nesouhlasím & 108 & 9,47 & 100,00 \\
\hline celkem & 1141 & 100 & $\mathrm{x}$ \\
\hline
\end{tabular}

Zdroj: vlastní zpracování

Z tabulky 11 vyplývá, že téměř $55 \%$ respondentů vyjádřilo nesouhlas s tvrzením, že podmínky pro podnikání se za posledních 5 let zlepšily. Tento výsledek je poněkud 
překvapivý v kontextu snahy vlády ČR o zlepšení podnikatelského prostředí a podpory podnikání.

Ještě výraznější míra nesouhlasu vyplývá z tabulky 12 , kde $78 \%$ podnikatelů nesouhlasí s tvrzením, že administrativní zátěž se za posledních 5 let snížila. Modální kategorií je nesouhlas s tvrzením (téměř $54 \%$ ) a hodnota $\mathrm{pMo}>0,5$ a proto se jedná současně o kategorii majoritní. Tato skutečnost může být ovlivněna zejména častými legislativními změnami a také opatřeními k zamezení daňovým únikům, která však současně zvyšují administrativní zátěž podnikatelů.

Tabulka 12: Administrativní zátěž podnikatelů se za posledních pět let snížila.

\begin{tabular}{|l|r|r|r|}
\hline${\text { míra souhlasu } \mathrm{x}_{\mathrm{i}}} \mathrm{n}_{\mathrm{i}}$ & $\mathrm{p}_{\mathrm{i}}(\%)$ & $\mathrm{kp}_{\mathrm{i}}(\%)$ \\
\hline úplně souhlasím & 20 & 1,75 & 1,75 \\
\hline souhlasím & 107 & 9,38 & 11,13 \\
\hline nezaujímám postoj & 124 & 10,87 & 22,00 \\
\hline nesouhlasím & 613 & 53,72 & 75,72 \\
\hline úplně nesouhlasím & 277 & 24,28 & 100,00 \\
\hline celkem & 1141 & 100 & $\mathrm{x}$ \\
\hline
\end{tabular}

Zdroj: vlastní zpracování

Obrázek 5: Vývoj podmínek a administrativní zátěže

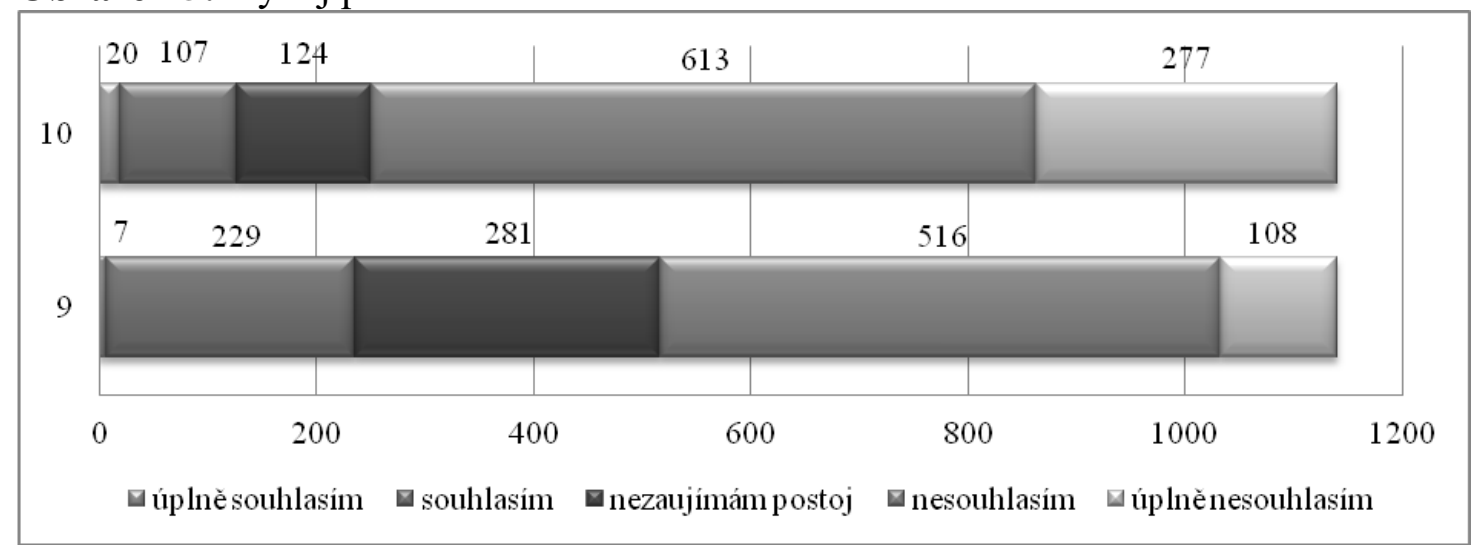

Zdroj: vlastní zpracování

Z obrázku 5 je zřejmé, že vývoj podmínek pro podnikání a administrativní zátěž je vnímána podnikateli negativně. Většina respondentů nesouhlasí s tím, že by vosledních 5 letech došlo ke zlepšení podmínek pro podnikání.

\section{Závěr}

Malé a střední podnikání představuje významnou součást každé vyspělé ekonomiky a jsou společensky důležité obzvláště z hlediska zaměstnanosti a ekonomického výkonu celé společnosti. Malé a střední podniky mají klíčovou roli při restrukturalizaci ekonomiky, zvyšování dynamiky trhu a v neposlední řadě mohou absorbovat podstatnou část pracovních sil uvolňovaných z velkých podniků.

V České republice reprezentují více než 1 milion ekonomických subjektů tj. 99,84 \% všech podnikatelů. Představují naprostou většinu všech podniků, podílejí se rozhodujícím způsobem na zaměstnanosti i vytváření nových pracovních míst a rovněž tvorbě domácího produktu, výkonech a přidané hodnotě. Je proto nezbytné, aby malí a střední podnikatelé měli pro svoji činnost vhodné prostředí, které by jim umožnilo rozvinout jejich schopnost přispívat k ekonomickému růstu a zachování a posilování sociální soudržnosti. 
Česká republika má eminentní zájem o zlepšení podnikatelského prostředí, snižování administrativní zátěže, podporu podnikání, zjednodušování legislativy, což vyplývá mezi jiným z programových prohlášení vlády. Agenda zaměřená na sledování snižování administrativní zátěže podnikatelů byla Českou republikou zahájena v roce 2005 , kdy byl schválen Akční plán snižování administrativní zátěže podnikatelů. Do roku 2014 bylo přijato celkem 79 opatření, jejichž cílem bylo zlepšení podmínek pro podnikatele. Bohužel malé a střední podniky se i prres postupné plnění opatření stále potýkají s množstvím překážek v podobě administrativních bariér a legislativních postupů a často čelí také špatné dostupnosti kapitálu. Jak vyplývá z novelizované legislativy, byla přijata některá opatření, která administrativní zátěž snížila. Na druhou stranu vzniká podnikatelům řada dalších povinností, které administrativu zvyšují, a to zejména pro malé a střední podniky vzhledem k jejich omezeným finančním zdrojům.

Cílem výzkumného šetření bylo proto zjištění, jak podnikatelé vnímají podmínky pro podnikání malých a středních podniků v České republice. Otázky byly pro účely vyhodnocení rozděleny do tři kategorií: jakým způsobem malé a střední fïmy vnímají podporu svých podnikatelských aktivit ze strany státu, ze strany okolí a veřejnosti, a jak se podle jejich názoru změnil vývoj podmínek a administrativní zátěže. Podpora státu je většinou respondentů vnímána jako nedostatečná, stejně tak podnikatelé nepocit’ují v posledních letech zlepšení podmínek pro podnikání ani snížení administrativní zátěže.

\section{Poděkování}

„Tento článek vznikl za podpory Ministerstva školství, mládeže a tělovýchovy ČR v rámci Institucionální podpory na dlouhodobý koncepční rozvoj výzkumné organizace v roce 2016 “

\section{Literatura}

[1] AHMAD, S. Z., 2012. Micro, small and medium-sized enterprises development in the Kingdom of Saudi Arabia: problems and constraints. World Journal of Entrepreneurship, Management and Sustainable Development, 8(4), 217-232. ISSN 2042-5961.

[2] BELÁS, J., P. BARTOŠ, A. KLJUČNIKOV a L. KOZUBÍKOVÁ, 2015. Významné determinanty kvality podnikatel'ského prostredia malých a stredných firiem. Scientific papers of the University of Pardubice, 22(35), 5-17. ISSN 1211-555X.

[3] BLACKBURN, R. A., M. HART, D. SMALLBONE, J. KITCHING, W. EADSON a K. BANNON, 2005. Analysis of the Impact of the Tax System on the Cash Flow of Small Businesses: A Report for HM Revenue and Customs (HMRC). Kingston: Business School. ISBN 1-872058-83-3.

[4] BLECHOVÁ, B., 2012. Progresivní nebo „rovná“ daň - ekonomické a politické dilema. Politická ekonomie, 60(5), 649-668. ISSN 0032-3233.

[5] DUJOWICH, J. P., 2010. A theory of serial entrepreneurship. Small Business Economics, 35(4), 377-398. ISSN 0921-898X.

[6] Evropská komise, 2010. EVROPA 2020 Strategie pro inteligentní a udržitelný růst podporujicí začleněni [online]. [vid 11. února 2014]. Dostupné z: www.mmr.cz/getmedia/7c31b211-1a5a-46a8-b6bd-151b72dc94ec/EU2020-CJ.pdf

[7] Evropská komise, 2015. User guide to the SME definitiv. Luxembourg: Publications Office of the European Union. ISBN 978-92-79-45322-9.

[8] GHAVIDEL, S., G. FARJADI a A. MOHAMMADPOUR, 2011. The relationship between entrepreneurship and unemployment in developed and developing countries. The International Journal of Economic Behavior - IJEB, 1(1), 71-78. ISSN 2285 - 0430. 
[9] KOZUBÍKOVÁ, L., J. BELÁS, Y. BILAN a P. BARTOŠ, 2015. Personal characteristics of entrepreneurs in the context of perception and management of business risk in the SME segment. Economics and Sociology, 8(1), 41-54. ISSN 2071-789X.

[10] KUBÍČKOVÁ, L. a L. PROCHÁZKOVÁ, 2014. Success evaluation of small and medium-sized enterprises in terms of their participation in the internationalization process. E + M Ekonomie a Management, 17(2), 131-145. ISSN 1212-3609.

[11] LACINA, L. a J. VAVŘINA, 2013. The impact of financial and economic crisis on SME's in Greece and Ireland. Acta Univ. Agric. Silvic. Mendelianae Brun., 61(4), 10051016. ISSN 1211-8516.

[12] LIGNIER, P. a C. EVANS, 2012. The rise and rise of tax compliance costs for the small business sector in Australia. Australian Tax Forum [online]. 27(3) [vid. 2. dubna 2013]. Dostupné z: papers.ssrn.com/sol3/papers.cfm?abstract_id=2128418

[13] Ministerstvo průmyslu a obchodu, 2013. Koncepce podpory malých a středních podnikatelì na obdobi let 2014-2020 [online]. [vid 11. ledna 2013]. Dostupné z: www.businessinfo.cz/cs/clanky/koncepce-politiky-msp-2014-2020-27913.html.

[14] Ministerstvo průmyslu a obchodu, 2015. Zpráva o pokroku ve snižování administrativní zátěže podnikatelů za rok 2014 [online]. [vid. 9. července 2015]. Dostupné z: www.mpo.cz/dokument 160157.html

[15] Programové prohlášení Vlády České republiky 4. srpna 2010. Vláda $\check{C} R$ [online]. [vid 2. ř́jna. 2015]. Dostupné z: www.vlada.cz/assets/media-centrum/dulezitedokumenty/Programove_prohlaseni_vlady.pdf

[16] ŘEZANKOVÁ, H., 2011. Analýza dat z dotazníkových šetření. Praha: Professional Publishing. ISBN 978-80-7431-062-1.

[17] SOPKOVÁ, E. a A. SUJOVÁ, 2011. Ways of using VAT in corporate finance. Economy \& Business, 2011(5), 1-10. Sofia: Bulgarian Academy of Sciences. ISSN 1313-2555.

[18] THURIK, A. R. et al., 2008. Does self-employment reduce unemployment? Journal of Business Venturing. 23(6), 673-686. ISSN 0883-9026.

[19] Úřad vlády ČR, 2006. Analýza administrativní zátěže podnikatelio [online]. [vid 24. ř́jna. 2015]. Dostupné z: www.cebre.cz/dokums_raw/reforma_statni_spravy.pdf

[20] VAŠTÍKOVÁ, M. a K. MATUŠÍNSKÁ, 2014. Satisfaction Rate of the Small and Medium Enterprises with the Corporate Environment of a Municipalities. Acta academica karviniensia, 14(2), 184-197. ISSN 1212-415X.

[21] VÍTEK, L. a J. PAVEL, 2008. Analýza nákladi̊ soukromého sektoru vyvolaných daňovým systémem [online]. Výzkumná studie. Praha: Vysoká škola ekonomická v Praze a Ministerstvo financí ČR [vid. 25. října 2013]. Dostupné z: www.mfcr.cz/cs/aktualne/tiskove-zpravy/2009/2009-08-10-tiskova-zprava-5431-5431.

[22] WEICHENRIEDER, A. J., 2007. Survey on the Taxation of Small and Medium-sized Enterprises [online]. Paris: OECD [vid. 2. dubna 2012]. Dostupné z: www.oecd.org/tax/taxpolicyanalysis/39597756.pdf

[23] Zpráva o vývoji malého a středního podnikání a jeho podpoře v roce 2014 vypracována Ministerstvem průmyslu a obchodu na základě zákona č. 47/2002 Sb., o podpoře malého a středního podnikání. MPO $\check{C} R$ [online]. [vid 24. záŕí. 2015]. Dostupné z: www.mpo.cz/dokument164106.html 